These he carefully translated and annotated, and numbers of the translations and remarks appeared in the scientific journals of the day both in India and in Europe. $\mathrm{He}$ was president of the Bombay branch of the East India Association, and up to the time of his illness constantly took part in the discussions of that body. His exertions in the cause of native female education procured for him the respect and gratitude of his more advanced fellow-countrymen. He established the Literary and Scientific Society, Bombay, and became its first president. His exertions to procure a recognised system of female education amongst the Hindoos were rewarded by a collection made by his admirers of some 12,000 rupees, which, at his request, was expended in establishing a school which has ever since been known by the name of "Bhau Dajee's Girls' School." He was elected a member of the Bombay Board of Education in 1852 . He also filled the presidential chair of the Grant Medical College Society. As vice-president of the Bombay branch of the Royal Asiatic Society, he devoted a considerable portion of his spare time to furthering the interests of the society, and to the museum he presented many valuable contributions. With all the leading public questions of his time Bhau Dajee was familiar, and invariably took part in their discussion. Although he was in possession of a large practice he never accumulated a fortune, as he always willingly and readily gave money for the relief of distress. One of his latest and most important discoveries in medical science was the cure for leprosy, which he was on the point of perfecting when seized with paralysis. While ill he was most anxious that his manuscripts should be collected and got ready for publication. This duty will, we understand, be performed by his brother, Dr. Narayen Dajee, himself an accomplished scholar and well-known medical practitioner. Dr. Bhau visited many parts of India, but never went to England, though we believe he had a strong inclination to do so. Numberless instances of his public spirit and generosity might be cited did our space permit.

The public services of Dr. Bhau Dajee have been so numerous and important that it is but right that steps should be taken to commemorate them by means of a memorial, and we hope that but a short period will be allowed to elapse before some definite proposal will be laid before the public.

The deceased doctor was a member of numerous scientific societies both in India, in Europe, and in America.

\section{OUR SULPHUR SUPPLIES}

GIGNOR PARODI has addressed a report to the Italian Government, in which he gives his estiinates that the sulphur of Sicily will be exhausted in fifty or sixty years. At present it is on Sicily we depend almost entirely for the supply of our sulphur-that "mainstay of present industrial chemistry "-which is so largely used in our arts and manufactures. Our demand, too, has been a steadily increasing one. In I 842 we imported 16,686 tons, and in 1862 the demand had risen to 75,000 tons. In the production of nearly every textile fabric sulphuric acid is used; it is more or less directly employed in soap and glass-making, metal refining, and the preparation of artificial manures requires large quantities. Our consumption seems to be limited only by the supply.

Recently a correspondent in the fournal of the Society of Arts stated, from his own experience of Sicily, that "with few exceptions, the ore is carried to the surface on the backs of boys. . . The produce of a mine in Sicily is chiefly determined by the difficulty of getting boys . . . and the mines soon reach a depth at which they cease to be profitably worked. All the sulphur in the island, therefore, below 400 feet is untouched." He consequently doubts the correctness of Signor Parodi's estimate.

Still this report of Signor Parodi's is likely to cause some uneasiness, and the prospects of our obtaining a large supply at a cheap rate from Iceland must not be forgotten. The island is but two days' journey from Scotland, and from recent reports on the harbours there seems no reason why a continual intercourse might not be kept up. Many travellers have borne testimony to the immense fields of unworked sulphur there, and the fresh deposition in worked districts is stated to take place at a wonderfully rapid rate. In the celebrated solfatara of Puzzuoli, near Naples, after the mixture of gravel and sulphur has been submitted to the distillation of the sulphur, the gravel is returned, and in thirty years is again so rich in sulphur as to admit of the same process. In Iceland this renewal of sulphur in the gravel is said to occupy but three years; the supply is therefore practically inexhaustible. Estimates show that while Sicilian sulphur is $5 l$. $x 7$ s. a ton in Britain, Icelandic would be about $2 l$. I $8 s$. a ton.

According to a pamphlet by Dr. Carter Blake, recently issued, we learn that a lease for working some of the mines in the northern and eastern provinces of Iceland has been granted to Mr. Lock, of London.

\section{A GREAT TELESCOPE}

WE have already referred to the series of splendid gifts from Mr. James Lick, from San Francisco, to the State of California, the whole amounting to $2,000,000$ dols. The most remarkable of these donations is one of 700,000 dols. for the purpose of erecting and endowing an astronomical observatory, and equipping it with " a powerful telescope, superior to, and more powerful than, any telescope ever yet made." The author of this magnificent bequest (the Nere York Times states) is in every sense of the word a self-made man, and has followed the wise example of the founders of our Cooper Institute and Lennox Library in securing the proper fulfilment of his trust by providing for its organisation in his lifetime. The United States already possess in the telescope of the Naval Observatory at Washington an instrument of the same gigantic proportions as that erected by $\mathrm{Mr}$. Newall in this country; and we may add that this was the first instrument constructed after $\mathrm{Mr}$. Newall had shown by his costly experiment that such dimensions were possible. The glass for the lenses of both these instruments was furnishel by Chance and Co., of Birmingham, England. Under Mr. Lick's gift, Messrs. Alvan Clark and Sons are designated as the final judges of the most appropriate site for the proposed great telescope of California and of the world. How amply endowed will be the Lick Observatory, on the summit of the Sierra, may be conjectured from the fact that the great Washington telescope cost but 44,000 dols. The trustees who have the spending of the 700,000 dols. will be limited simply by the ability of the glass-makers to turn out a lens of sufficient size. We assume (continues the above paper) that the proposed telescope will be a refractor, since the great reflectors, of which the best known are Herschel's and Rosse's, have been found comparatively useless for accurate observations. The great speculum or object-mirror of the former was $49 \frac{1}{2}$ in. diameter, and the latter had two specula of $6 \mathrm{ft}$. diameter. Both were among the marvels of the generations that saw them constructed; but the latter, albeit only thirty years old, is nearly as much out of date as the former, which was constructed eighty-five years ago. It is just possible that the existence of a bequest large enough to yield six times the price which has ever been paid for a telescope may be the means of giving birth to lenses of what would norv be reckoned impossible size and perfection. The 26 -in. object lens of the Washington telescope has been duplicated in the one ordered by $\mathrm{Mr}$. $\mathrm{M}^{\prime}$ Cormick, of Chicago, for the Washington and Lee University of Lexington; but, though larger lenses have been talked of, their successful production is still problematical. Many costiy * Ure's Dict. of Arts, \&c., rol. iii., p. 830 . 